\title{
HUBUNGAN POLA MAKAN, UMUR DAN PENGETAHUAN DENGAN KEJADIAN HIPERTENSI PADA IBU HAMIL DI KABUPATEN ACEH BESAR
}

\author{
T.M. Rafsanjani ${ }^{1}$, Yasir $^{2}$, Masyudi $^{3}$ \\ ${ }^{1,2,3}$ Fakultas Kesehatan Masyarakat Universitas Serambi Mekkah, Aceh \\ tmrafsanjani@serambimekkah.ac.id
}

\begin{abstract}
He maternal mortality rate in 2014 at the Profile of the Aceh Besar District Health Office, was 29 people with cases of preeclampsia (20.8\%), bleeding (20.8\%), infection / sepsis (34.5\%), and other causes (24.1\%). And Based on preliminary surveys conducted by researchers at the Krueng Barona Jaya Health Center, Krueng Barona Jaya District, Aceh Besar Regency, it is known that in January to May 2017 there were 367 pregnant women visiting and of them having 122 high blood pressure. This is a direct cause of maternal death during labor. This study is an Analytical study with cross sectional design. Data collection using a questionnaire. Samples in this study were 96 respondents, with data analysis used were univariate and bivariate. The place of this research was conducted at the Krueng Barona Jaya Health Center, Krueng Barona Jaya District, Aceh Besar Regency in 2017. Based on the results of the chi-square statistical test it can be concluded that there is a relationship between age and hypertension in pregnant women $(P$-value $0.004<0.05)$ with OR 3,722, there is a relationship of knowledge with hypertension in pregnant women $(P$-value $0.002<0.05)$ with OR 4.142 and there is a relationship between diet and hypertension in pregnant women $(P$-value $0.007<0.05)$ with OR 3.429 in the Krueng Health Center Barona Jaya Krueng District Barona Jaya Great Aceh District 2017. The conclusion of this research is there are correlations between age, knowledge and dietary habit toward hypertensions on pregnant mother in the Puskesmas working area of Krueng Barona Jaya Aceh Besar. It is expected that Puskesmas and health workers can improve services and counseling about the importance of pressure checks during pregnancy.
\end{abstract}

Keywords: hypertension, pregnant women, knowledge, diet.

\begin{abstract}
ABSTRAK
Berdasarkan Profil Dinas Kesehatan Aceh Besar Angka kematian ibu tahun 2014 sebanyak 29 orang dengan kasus preeklampsia sebanyak (20,8\%), perdarahan sebanyak (20,8\%), infeksi/sepsis sebanyak (34,5\%), dan penyebab lain sebanyak (24,1\%). Dan Berdasarkan survei awal yang dilakukan peneliti di Puskesmas Krueng Barona Jaya Kecamatan Krueng Barona Jaya Kabupaten Aceh Besar, diketahui bahwa pada bulan Januari sampai Mei 2017 didapatkan data jumlah kunjungan ibu hamil sebanyak 367 ibu dan diantaranya memiliki tekanan darah tinggi sebanyak 122 ibu hamil. Hal ini penyebab langsung kematian ibu pada saat persalinan. Penelitian ini bersifat Survei Analitik dengan desain cross sectional, Pengumpulan data menggunakan kuisioner. Sampel pada penelitian ini sebanyak 96 responden, dengan analisis data yang digunakan adalah univariat dan bivariat. Tempat penelitian ini dilakukan di Wilayah Kerja Puskesmas Krueng Barona Jaya Kabupaten Aceh Besar Tahun 2017. Dari hasil uji statistik chi-square dapat disimpulkan bahwa ada hubungan antara umur dengan hipertensi pada wanita hamil ( $\mathrm{p}$ value $0,004<0,05$ ) dengan OR 3.722, ada hubungan pengetahuan dengan hipertensi pada wanita hamil ( $\mathrm{p}$ value $0,002<0,05$ ) dengan OR 4.142 dan terdapat hubungan antara pola makan dengan hipertensi pada wanita hamil ( $\mathrm{p}$ value $0,007<0,05$ ) dengan OR 3.429 di Puskesmas Krueng Barona Jaya Kecamatan Krueng Barona Jaya Kabupaten Aceh Besar Tahun 2017. Dapat disimpulkan bahwa, terdapat hubungan umur, pengetahuan dan pola makan dengan kejadian hipertensi pada wanita hamil di Wilayah Kerja Puskesmas Krueng Barona Jaya Kabupaten Aceh Besar. Diharapkan kepada Puskesmas dan petugas kesehatan dapat meningkatkan pelayanan dan penyuluhan tentang pentingnya pemeriksaan tekanan dalam masa kehamilan.
\end{abstract}

Kata Kunci : hipertensi, ibu hamil, pengetahuan, pola makan. 


\section{PENDAHULUAN}

Kehamilan tidak semua dapat berjalan dengan lancar, pada kondisi hamil, sering ditemukan berbagai risiko yang dapat mempengaruhi kesehatan dan mengancam jiwa ibu maupun kandungannya. Diantara beberapa permasalahan yang sering dijumpai adalah hipertensi pada masa kehamilan. Kondisi ini mengakibatkan tingginya angka kesakitan dan kematian yang pada akhirnya menjadi permasalahan kesehatan masyarakat secara umum (Chen et al., 2006). Kehamilan seseorang, sangat dipengaruhi oleh kematangan fisik, psikologi pada masa remaja, pada masa ini merupakan fase, di mana fungsi fisik mendekati kesempurnaan, atau hampir memenuhi puncaknya (Darusman \& Rafsanjani, 2018).

Berbagai faktor risiko kehamilan, adalah usia kehamilan dini (usia muda/remaja), yang merupakan usia ibu waktu mengandung < 20 Tahun. Kehamilan dini disebabkan oleh berbagai faktor, salh satunya adalah sex diluar nikah maupun paksaan keluarga atau keinginan sendiri. Usia ideal untuk ibu hamil serta melahirkan pada umur 20-30 tahun, jika kehamilan lebih kurang atau melebihi usia tersebut, akan akan memiliki risiko kematian 2 hingga 4 x lebih dibandingkan dengan usia tidak ideal untuk hamil (Manuaba, 2010).

Kejadian hipertensi pada masa hamil (Preeklampsia dan Eklampsia) merupakan salah satu dari berbagai penyebab utama kematian ibu secara, setelah kejadian infeksi dan perdarahan (Hasan, 2007).

Kementerian Kesehatan (Kemenkes) mengemukakan bahwa, dari aspek dampak, hipertensi adalah suatu penyakit berbahaya, terutama bila terjadi pada masa kehamilan, kondisi ini dapat berdampak pada kematian ibu atau bayi yang akan dilahirkan. Permasalahan lainnya pada hipertensi adalah, jarang ditemukan gejala atau suatu tanda tertentu sebagai peringatan awal. Kejadian Hipertensi pada masa hamil atau preeklampsia masih dikategorikan tinggi, dengan persentase sebesar $12 \%$ dari semua kematian ibu di dunia (Rohman dkk., 2015).

Berdasarkan jenisnya, hipertensi secara umum dibagi menjadi empat jenis, yang umumnya menderita pada masa hamil, yaitu: 1) Tekanan darah tinggi (hipertensi) diakibatkan kehamilan/keracunan, (tekanan darah tinggi juga disertai dengan kelainan pada urine ibu hamil). Preeklamsia merupakan permasalahan yang muncul dengan gejala/tanda hipertensi, proteinuria dan edema dikarenakan kehamilan. 2) Hipertensi kronik, adalah kondisi meningkatnya tekanan darah tinggi bawaan sebelum masa kehamilan. 3) Preeklampsia pada hipertensi kronik, adalah gabungan antara preeklampsia dengan hipertensi kronik. 4) Hipertensi gestasional atau disebut juga hipertensi sesaat. Perkembangan sampai saat ini bahwa penyebab hipertensi pada masa hamil belum diketahui secara jelas, ada beberapa pendapat yang menjelaskan bahwa di sebabkan oleh kelainan pembuluh darah, dan faktor menjaga pola makan, pendapat lain juga menjelaskan, bahwa hipertensi pada hipertensi pada masa kehamilan disebabkan faktor genetik dan lain sebagainya (Pusdatin Kementerian RI, 2014).

Merujuk pada berbagai faktor risiko penyebab hipertensi, maka diketahui ada faktor risiko yang tidak dapat dikendalikan seperti : umur, jenis kelamin, riwayat keluarga dan genetik dan faktor risiko yang dapat dikendalikan yaitu: kebiasaan merokok, konsumsi garam, stres, penggunaan jelantah,obesitas, kebiasaan konsumsi minumminuman beralkohol, konsumsi lemak jenuh, kurang aktifitas fisik, penggunaan estrogen dan berbagai faktor lainya akibat gaya hidup (Pusdatin Kementerian RI, 2014).

Berdasarkan hasil penelitian yang terkait dilakukan di Rumah Sakit Umum Daerah dr. Zainoel Abidin tahun 2014 diperoleh sebesar 105 kasus preeklamsia dari 2.105 ibu hamil (4,9\%). Hasil penelitian ini, dapat disimpulkan bahwa, ibu bersalin yang preeklampsia berisiko 26,8 kali untuk menderita hipertensi jika dibandingkan dengan ibu bersalin tidak preeklamsia (Afridayani, 2016).

Badan Kesehatan Dunia (WHO) menjelaskan bahwa, ibu meninggal dunia pada masa kehamilan atau masa bersalin sebesar 585.000 setiap tahunnya, dan diketahui sebesar 58,1\% disebabkan karena preeklampsia dan eklampsia. Kematian ibu di Indonesia yang disebabkan oleh preeklampsi dan eklampsi sekitar 15\% - 25\%. Beberapa penyakit yang diderita oleh ibu yang menyebabkan tingginya risiko terhadap preeklampsia, diantaranya adalah diabetes mellitus, riwayat hipertensi kronis, ginjal kronis, pre eklampsia, hiperplasentosis (mola hidatidosa, kehamilan multiple dan bayi besar) dan ginjal kronis (Prawirohardjo, 2009). 
Survei Demografi dan Kesehatan Indonesia (SDKI) pada tahun 2015 merelease data, bahwa kasus kematian ibu semakin meningkat. Diketahui tahun 2015 Angka Kematian Ibu Indonesia terjadi peningkatan dari 228 tahun 2007 menjadi 359 per 100.000 kelahiran hidup (KH) pada tahun 2015, Kondisi ini belum memenuhi target yang ditentukan pemerintah, yaitu 102 kasus per 100.000 kelahiran hidup pada tahun 2016. (Rigina, 2016).

Kondisi prevalensi hipertensi di provinsi Aceh diketahui sebesar 12,6\% (Badan Penelitian dan Pengembangan Kesehatan, 2013). Menurut data dari Riskesdes tahun 2013 bahwa jumlah penderita hipertensi mencapai 21,5\% (Badan Penelitian dan Pengembangan Kesehatan, 2013). Berdasarkan profil Dinas Kesehatan Provinsi Aceh, diketahui bahwa pada tahun 2010, kasus hipertensi menduduki peringkat ke empat, dengan kategori penyakit banyak diderita oleh masyarakat Aceh, sebesar 474 kasus.

Berdasarkan profil Dinas Kesehatan Aceh Besar, diketahui bahwa jumlah ibu hamil di Kab. Aceh Besar pada tahun 2014 sebanyak $13.602 \mathrm{ibu}$, dari jumlah tersebut, sebanyak 2.113 kasus (76.1\%) berhasil ditangani komplikasi yang diderita. Namun angka kematian ibu pada tahun 2014 sejumlah 29 orang dengan faktor penyebab adalah preeklampsia sebesar $6(20,8 \%)$ orang, perdarahan sebesar $6(20,8 \%)$ orang, infeksi sebanyak $10(34,5 \%)$ orang, dan penyebab lain sebesar $7(24,1 \%)$ orang (Dinas Kesehatan Provinsi Aceh, 2014).

Menurut data survei awal, yang diperoleh dari Puskesmas Krueng Barona Jaya Kabupaten Aceh Besar Tahun 2017 bahwa kunjungan pasien secara keseluruhan yang mengalami Hipertensi sebanyak 517 orang yang dihitung dari bulan Maret sampai Desember 2016.

Kondisi masyarakat di wilayah Krung Barona Jaya masih ditemukan ibu hamil yang tidak memperhatikan kesehatan kehamilannya, dari aspek pola makan, kemauan pemeriksaan kehamilan dan masih rendahnya pemahaman ibu hamil tentang kehamilan.

Hamil menjadi permasalahan yang masih didapatkan di wilayah Krueng Barona Jaya yaitu usia yang masih muda, diet dan belum memahami kondisi kehamilan, sehingga tidak peduli dengan kebutuhan-kebutuhan masa kehamilan.

Berdasarkan latarbelakang di atas, maka penulis tertarik melakukan penelitian ini dengan tujuan untuk mengetahui faktor yang berhubungan dengan kejadian Hipertensi pada ibu Hamil di wilayah Kerja Puskesmas Krueng Barona Jaya Kabupaten Aceh Besar.

\section{METODE}

Penelitian ini bersifat deskriptif analitik dengan desain cross sectional. Populasi pada penelitian ini adalah seluruh wanita Hamil yang mengalami hipertensi di Wilayah Kerja Puskesmas Krueng Barona Jaya dengan jumlah sampel sebanyak 96 orang ibu Hamil, diperoleh dari hasil rumus Lemeshow, penelitian dilakukan pada responden dengan memenuhi kriteria inklusi: a) Berusia $<20$ sampai dengan > 35 tahun, b) Wanita Hamil yang mengalami hipertensi ringan 120/80$140 / 90$ dan berat $\geq 140 / 90$ berdasarkan riwayat rekam medik dan pemeriksaan kembali oleh tenaga perawat, c) Bisa baca dan tulis, d) Bersedia dijadikan responden.

Pengambilan sampel menggunakan teknik non probability sampling yaitu Incidental Sampling. Responden di wawancara adalah yang secara kebetulan bertemu di puskesmas dan memenuhi kriteria untuk diteliti, dalam wawancara yang dilakukan dengan menggunakan kuisioner dan terfokus pada variabel umur yang berisiko $<20$ Th dan $>35 \mathrm{Th}$, pengetahuan ibu, dimana pengetahuan mengkaji tentang Segala sesuatu yang diketahui ibu hamil tentang hipertensi, pengetahuan dikategorikan rendah bila mampu menjawab pertanyaan dengan benar $\leq 50 \%$ dan dikategorikan tinggi jika benar menjawab $>50 \%$, dan pola makan ibu, dimana pola makan yang dilihat adalah menu atau asupan makanan yang dikonsumsi oleh ibu selama kehamilan dengan kesesuaian gizi dengan kecukupan karbohidrat, sayuran, buah-buahan, protein, produk susu dan menghindari pantangan-pantangan yang tidak ilmiah, pola makan dikategorikan sesuai bila menjawab pertanyaan dengan benar $\leq 50 \%$ dan tidak sesuai jika benar menjawab $>50 \%$ dari hasil skor kuisioner. Analisis data yang dilakukan adalah univariat dan bivariat dengan menggunakan chi square test. 


\section{HASIL}

Berdasarkan hasil pengumpulan data dengan kuesioner serta ditabulasi yang dilakukan di Wilayah Kerja Puskesmas Krueng
Barona Jaya Kabupaten Aceh Besar pada 96 responden diperoleh hasil bahwa :

Tabel 1. Gambaran Karakteristik Responden di Wilayah Kerja Puskesmas Krueng Barona Jaya Kabupaten Aceh Besar Tahun 2017

\begin{tabular}{|c|c|c|c|}
\hline No & Karakteristik Responden & Jumlah & $\%$ \\
\hline \multicolumn{4}{|c|}{ Hipertensi Ibu Hamil } \\
\hline 1 & Berat $(\geq 140 / 90 \mathrm{~mm} \mathrm{Hg})$ & 44 & 45,8 \\
\hline 2 & Ringan (120/80-140/90 mm Hg) & 52 & 54,2 \\
\hline \multicolumn{2}{|r|}{ Jumlah } & 96 & 100 \\
\hline \multicolumn{4}{|c|}{ Umur } \\
\hline 1 & Berisiko $(<20$ Th dan $>35 \mathrm{Th})$ & 49 & 51 \\
\hline 2 & Tidak Berisiko (20-35 Th) & 47 & 49 \\
\hline \multicolumn{2}{|r|}{ Jumlah } & 96 & 100 \\
\hline
\end{tabular}

Sumber: data primer

Berdasarkan tabel 1, dapat disimpulkan bahwa, dari 96 responden ibu hamil, diketahui $54,2 \%$ dengan kondisi

hipertensi ringan, dan $51 \%$ dengan umur yang berisiko terhadap kejadian hipertensi $(<21$ tahun dan $>35$ tahun).

Tabel 2. Hubungan Umur dengan Hipertensi pada Ibu Hamil di Wilayah Kerja Puskesmas Krueng Barona Jaya Kabupaten Aceh Besar Tahun 2017

\begin{tabular}{|c|c|c|c|c|c|c|c|c|c|c|}
\hline \multirow{3}{*}{ No } & \multirow{3}{*}{ Umur } & \multicolumn{4}{|c|}{ Hipertensi Ibu Hamil } & \multirow{2}{*}{\multicolumn{2}{|c|}{ Jumlah }} & \multirow{2}{*}{$\begin{array}{c}\mathbf{p} \\
\text { value }\end{array}$} & \multirow[b]{2}{*}{$\alpha$} & \multirow{2}{*}{ OR } \\
\hline & & \multicolumn{2}{|c|}{ Berat } & \multicolumn{2}{|c|}{ Ringan } & & & & & \\
\hline & & $\mathbf{N}$ & $\%$ & $\mathbf{N}$ & $\%$ & $\mathbf{N}$ & $\%$ & \multirow{4}{*}{0,004} & \multirow{4}{*}{0,05} & \multirow{4}{*}{3,722} \\
\hline 1 & $\begin{array}{l}\text { Berisiko }(<20 \text { tahun } \\
\text { dan }>35 \text { tahun })\end{array}$ & 30 & 61,2 & 19 & 38,8 & 49 & 100 & & & \\
\hline 2 & $\begin{array}{l}\text { Tidak Berisiko (20- } \\
35 \text { tahun) }\end{array}$ & 14 & 29,8 & 33 & 70,2 & 47 & 100 & & & \\
\hline \multicolumn{2}{|r|}{ Jumlah } & 44 & 45,8 & 52 & 54,2 & 96 & 100 & & & \\
\hline
\end{tabular}

\section{Sumber: data primer}

Tabel 2 menunjukkan bahwa dari 49 responden, yang memiliki umur berisiko hipertensi $(<21 \mathrm{Th}$ dan $>35 \mathrm{Th})$ sebanyak 30 responden $(61,2 \%)$ mengalami hipertensi berat dan 19 responden $(38,8 \%)$ mengalami hipertensi ringan, dibandingkan dari 47 responden yang memiliki umur tidak beresiko hipertensi (21-35 Th) sebanyak 14 responden $(29,8 \%)$ mengalami hipertensi berat dan 33 responden $(70,2 \%)$ mengalami hipertensi ringan.
Berdasarkan uji statistik dengan menggunakan Uji Chi-Square didapatkan nilai $p$ value sebesar $0,004<$ dari nilai $\alpha=0,05$, maka Ha diterima, hal ini menunjukkan ada hubungan umur dengan hipertensi pada ibu hamil. Hasil penelitian ini diperoleh nilai $\mathrm{OR}=$ 3,722 , yang berarti bahwa umur responden atau ibu hamil beresiko 3,7 kali menderita hipertensi berat dibandingkan dengan hipertensi ringan.

Tabel 3. Hubungan Pengetahuan dengan Hipertensi pada Ibu Hamil di Wilayah Kerja Puskesmas Krueng Barona Jaya Kabupaten Aceh Besar Tahun 2017

\begin{tabular}{|c|c|c|c|c|c|c|c|c|c|c|}
\hline \multirow{3}{*}{ No } & \multirow{3}{*}{ Pengetahuan } & \multicolumn{4}{|c|}{ Hipertensi Ibu Hamil } & \multirow{2}{*}{\multicolumn{2}{|c|}{ Jumlah }} & \multirow{2}{*}{$\begin{array}{c}P \\
\text { value }\end{array}$} & \multirow{2}{*}{$\alpha$} & \multirow{2}{*}{ OR } \\
\hline & & \multicolumn{2}{|c|}{ Berat } & \multicolumn{2}{|c|}{ Ringan } & & & & & \\
\hline & & $\mathbf{N}$ & $\%$ & $\mathbf{N}$ & $\%$ & $\mathbf{N}$ & $\%$ & \multirow{4}{*}{0,002} & \multirow{4}{*}{0,05} & \multirow{4}{*}{4,142} \\
\hline 1 & Tinggi & 31 & 62,0 & 19 & 38 & 50 & 100 & & & \\
\hline 2 & Rendah & 13 & 28,3 & 33 & 71,7 & 46 & 100 & & & \\
\hline \multicolumn{2}{|c|}{ Jumlah } & 44 & 45,8 & 52 & 54,2 & 96 & 100 & & & \\
\hline
\end{tabular}

Sumber: data primer 
Berdasarkan tabel 3 diperoleh hasil bahwa dari 50 responden, yang menyatakan berpengetahuan tinggi sebanyak 31 responden (62\%) mengalami hipertensi berat dan 19 responden $(38 \%)$ mengalami hipertensi ringan, dibandingkan dari 46 responden yang menyatakan berpengetahuan rendah sebanyak 13 responden $(28,3 \%)$ mengalami hipertensi berat dan 33 responden $(71,7 \%)$ dengan hipertensi ringan pada wanita hamil.
Berdasarkan uji statistik dengan menggunakan Uji Chi-Square didapatkan $\mathrm{p}$ value sebesar $0,002<$ dari nilai $\alpha=0,05$, maka $\mathrm{Ha}$ diterima, artinya ada hubungan pengetahuan dengan hipertensi pada wanita Hamil. Diketahui hasil OR $=4,142$ yang berarti bahwa responden dengan pengetahuan rendah berisiko 4,1 kali menderita hipertensi berat dibandingkan responden dengan pengetahuan tinggi.

Tabel 4. Hubungan Pola Makan dengan Hipertensi pada Ibu Hamil di Wilayah Kerja Puskesmas Krueng Barona Jaya Kabupaten Aceh Besar Tahun 2017

\begin{tabular}{|c|c|c|c|c|c|c|c|c|c|c|}
\hline \multirow{3}{*}{ No } & \multirow{3}{*}{ Pola Makan } & \multicolumn{4}{|c|}{ Hipertensi Ibu Hamil } & \multirow{2}{*}{\multicolumn{2}{|c|}{ Jumlah }} & \multirow{2}{*}{$\begin{array}{c}p \\
\text { value }\end{array}$} & \multirow{2}{*}{$\alpha$} & \multirow{2}{*}{ OR } \\
\hline & & \multicolumn{2}{|c|}{ Berat } & \multicolumn{2}{|c|}{ Ringan } & & & & & \\
\hline & & $\mathbf{N}$ & $\%$ & $\mathbf{N}$ & $\%$ & $\mathbf{N}$ & $\%$ & \multirow{4}{*}{0,007} & \multirow{4}{*}{0,05} & \multirow{4}{*}{3,429} \\
\hline 1 & Sesuai & 30 & 60 & 20 & 40 & 50 & 100 & & & \\
\hline 2 & Tidak Sesuai & 14 & 30,4 & 32 & 69,6 & 46 & 100 & & & \\
\hline & Jumlah & 44 & 45,8 & 52 & 54,2 & 96 & 100 & & & \\
\hline
\end{tabular}

Sumber: data primer

Berdasarkan tabel 4. Dapat didefinisikan bahwa dari 50 responden yang menyatakan pola makan sesuai sebanyak 30 responden $(60 \%)$ mengalami hipertensi berat dan 20 responden $(40 \%)$ yang mengalami hipertensi ringan, dibandingkan dari 46 responden yang menyatakan pola makan tidak sesuai sebanyak 14 responden $(30,4 \%)$ mengalami hipertensi berat dan 32 responden $(69,6 \%)$ dengan hipertensi ringan pada wanita hamil.

Berdasarkan uji statistik dengan menggunakan Uji Chi-Square didapatkan hasil $p$ value sebesar $0,016<$ dari nilai $\alpha=0,05$, maka Ha diterima. Hal ini menunjukkan ada hubungan pola makan dengan hipertensi pada wanita Hamil. Hasil penelitian ini juga didapatkan nilai $\mathrm{OR}=3.429$, berarti bahwa responden dengan pola makan tidak sesuai beresiko 3,4 kali menderita hipertensi berat dibandingkan responden dengan pola makan sesuai.

\section{PEMBAHASAN}

Umur merupakan ukuran usia seorang ibu yang secara umum menjadi batasan atau tolak ukur untuk status kedewasaan, baik pada pengambilan keputusan yang berdsarkan pada pengalaman-pengalaman yang diperoleh selama masa kehidupan. Usia sangat berhubungan dengan kepatuhan seorang ibu pada saat menghadapi proses kehamilan, usia ibu yang lebih muda mengakibatkan ketidaksiapan mental dan fisik seorang ibu untuk menerima kehamilannya, pada akhirnya akan berdampak pada terganggunya proses normalitas masa kehamilan, seperti hipertensi dan berbagai permasalahan lainnya (Rigina, 2016).

Tekanan darah tinggi merupakan kondisi penyakit kronis yang sangat sering ditemukan pada ibu hamil hamil dengan usia dewasa atau tua. Satu dari 10 ibu hamil berpotensi menderita hipertensi selama masa kehamilan. Secara spesifik, usia yang memiliki faktor risiko lebih besar adalah pada wanita pada usia 30-40 tahun dibanding ibu hamil pada usia lebih muda. Hipertensi pada ibu hamil dapat berdampak pada kondisi kesehatan ibu, janin atau anaknya. Secara fisiologis, bayi yang berkembang dalam rahim diberi pasokan oksigen dan nutrien melaului pembuluh darah. Tekanan darah tinggi dapat menyempitkan pembuluh darah pada rahim yang berimbas pada lambatnya penyaluran oksigen dan nutrien dari ibu menuju tubuh bayi, kondisi ini akan berdampak pada lambatnya perkembangan janin (Afridayani, 2016).

Penelitian ini sejalan yang dilakukan oleh Setyawati dkk., (2015) hasil analisis dari data Riset Kesehatan Dasar (Riskesdas) tahun 2013 pada tanggal 26 Februari 2015 adalah usia ibu hamil yang terkena hipertensi rata-rata berumur di atas 35 tahun. Pada penelitian ini dikelompokkan analisis umur responden yaitu menjadi dibawah 35 tahun dan di atas 35 
tahun. Pada penelitian terkait lainnya juga menunjukkan keterkaitan umur dengan kejadian hipertensi pada masa kehamilan dan terdapat hubungan umur maternal terhadap kasus hipertensi dalam kehamilan dengan umur > 35 tahun berisiko 2.7 kali terjadi hipertensi masa kehamilan dibandingkan dengan usia lebih muda.

Dapat disimpulkan bahwa umur ibu pada saat hamil dapat berpengaruh pada setiap keputusan dan tindakan dalam memilih tempat pemeriksaan dan paling penting adalah pada memiliki makanan yang dapat mempengaruhi hipertensi akibat makanan. Demikian pula dengan umur suami jika umur lebih tua maka pengetahuan tentang semua penjelasan yang berhubungan dengan cara pencegahan hipertensi akan bertambah pula.

Pengetahuan merupakan bentuk tahu atau mengetahui, yang diperoleh dari hasil kerja penglihatan dan perasaan manusia suatu objek yang diamati. Proses penginderaan dilakukan dengan panca indra manusia seperti, penglihatan, rasa, raba, indera pengdengaran dan penciuman. Pengetahuan adalah landasar untuk membentuk karakter dan tindakan seseorang (Notoatmodjo, 2010).

Pengetahuan memberikan dampak pada pemahaman individu, pengetahuan menjadi dasar penting untuk memilih tindakan yang akan di ambil. Pengetahuan juga mempengaruhi perilaku dan sikap seseorang terhadap permasalahan kesehatan, serta menjadi pertimbangan untuk pemilihan segala sesuatu tentang hidup sehat, dan tentang pemilihan tindakan dan keputusan tentang kehamilannya. Orang dengan tingkat pengetahuan tinggi akan berusaha untuk mengaplikasikan kemampuannya pada kehidupan kesehariannya (Rafsanjani, 2018).

Seorang ibu hamil tidak boleh berhenti belajar mengenai kehamilan jika ingin memiliki anak yang cerdas. Artinya seorang ibu harus selalu mencari tahu apa yang dapat dan mampu dilakukan agar perkembangan otak janin sempurna. Untuk itu ibu hamil perlu memiliki pengetahuan tentang kehamilan yang dapat membuat otak janin dapat berkembang sempurna dan nantinya dapat menjadi anak yang cerdas. Ibu hamil dengan tingkat pengetahuan rendah menjadi faktor risiko penyebab kematian ibu saat melahirkan dan bayi bahkan balitanya. Pengetahuan ibu hamil merupakan suatu hal yang sangat penting, dengan tujuan terjaga dan terpeliharanya kandungan dengan baik dan sehat, membantu kematangan psikis, dapat mencegah preeklampsia pada ibu hamil kehamilan dan kesiapan fisik proses persalinan (Wijaya, 2014).

Hasil penelitian ini sejalan yang dilakukan oleh Setyawati., dkk., (2015) di dapat hipertensi pada wanita hamil di Indonesia adalah berpendidikan dibawah Sekolah Menengah Pertama (SMP) (74,2\%) dengan $\mathrm{P}$ Value $=0,013$, bahwa pendidikan dan pengetahuan dapat berpengaruh terhadap pemanfaatan dan pemilihan fasilitas kesehatan.

Dapat disimpulkan, Pengetahuan ibu-ibu tentang kehamilan dan kesehatan anak adalah salah satu faktor yang mempengaruhi ibu yang akan mempunyai balita. Tingkat pengetahuan yang semakin baik, maka semakin luas wawasan dan informasi yang diperoleh.

Kondisi keteraturan pola makan manusia masih banyak yang tidak teratur dalam kehidupan sehari-hari, hal ini akan berdampak buruk pada kondisi kesehatan. Seorang wanita sebelum mempersiapkan diri untuk hamil, pasangan suami istri harus menjaga pola makan mereka. Pola makan yang sehat akan menjadikan tubuh senantiasa sehat. Dalam kondisi yang sehat, maka benih yang dihasilkan pun sehat (Chomaria, 2010).

Timbulnya suatu penyakit dipengaruhi oleh gaya hidup atau pola makan secara spesifik, pola makan yang teratudapat mencegah terjadinya suatu penyakit, atau menjaga kebugaran tubuh. Perilaku mengkonsumsi garam secara berlebihan, akan mengakibatkan rasa haus dan mendorong untuk minum, kondisi ini akan meningkatkan jumlah darah dalam tubuh, yang berdampak pada meningkatnya fungsi jantung untuk lebih giat memompa darah, sehingga tekanan darah akan naik, kenaikan fungsi jantung ini, berakibat pada banyaknya garam dan air yang harus di saring oleh ginjal yang dikarenakan masuk dan keluarnya darah harus sesuai. (Rohman, dkk., 2015).

Berdasarkan hasil penelitian serupa dilakukan oleh Sihotang et al., (2016) di Wilayah Kerja Puskesmas Biromaru Kabupaten Palu, menunjukkan bahwa pada umumnya responden terbiasa dengan pola makan baik sebesar 31 responden dan kurang baik sejumlah 10 responden. Berdasarkan hasil uji chi square, di dapat $P$-Value $=0,000$, dengan demikian terdapat hubungan antara 
pola makan ibu hamil dengan kejadian hipertensi.

Penelitian lainnya juga diketahui bahwa sebesar 38,2\% masyarakat secara individu masih memiliki pola makan, pemahaman dan perhatian terhadap diri sendiri yang kurang baik (Rafsanjani, 2018).

Dapat disimpulkan, wanita hamil memang membutuhkan nutrisi dan gizi yang baik dan cukup agar pertumbuhan bayi yang dalam kandungan dapat berkembang dengan baik dan sehat. Diketahui juga bahwa banyak wanita hamil yang tidak memperhatikan pola makan yang baik, dengan memperhatikan gizi seimbang yang berdampak pada terjadinya hipertensi pada saat hamil.

\section{KESIMPULAN}

Berdasarkan hasil penelitian, maka dapat disimpulkan bahwa terdapat hubungan umur $\geq 30$ Tahun dengan hipertensi pada ibu hamil di Wilayah Kerja Puskesmas Krueng Barona Jaya Kabupaten Aceh Besar Tahun 2017. Diperoleh hubungan pengetahuan rendah dengan hipertensi pada ibu hamil di Wilayah Kerja Puskesmas Krueng Barona Jaya Kabupaten Aceh Besar Tahun 2017. Ada hubungan pola makan_yang tidak sesuai (tidak memenuhi kesesuaian gizi, menu atau asupan makanan yang dikonsumsi oleh ibu selama kehamilan, kurangnya karbohidrat, sayuran, buah-buahan, protein dan produk susu) dengan hipertensi pada ibu hamil di Wilayah Kerja Puskesmas Krueng Barona Jaya Kabupaten Aceh Besar Tahun 2017.

\section{SARAN}

Ibu hamil yang berumur $<20$ tahun dan > 35 tahun diharapkan lebih sering melakukan pemeriksaan tekanan darah dalam masa kehamilan, disebabkan takut terjadinya beresiko hipertensi dalam masa kehamilan.

Ibu hamil diharapkan untuk meningkatkan pengetahuan tentang penyebab terjadinya hipertensi dalam masa kehamilan demi perkembangan buah hatinya.

Ibu hamil diharpkan untuk menjaga pola makan selama masa kehamilan agar tidak terjadinya hipertensi dalam masa kehamilan demi perkembangan buah hatinya.

Puskesmas dan petugas kesehatan diharapkan dapat meningkatkan pelayanan dan penyuluhan tentang pentingnya pemeriksaan tekanan dalam masa kehamilan dan diharapkan penelitian ini menjadi bahan perbandingan untuk penelitian lanjutan dengan kajian yang lebih mendalam.

\section{DAFTAR PUSTAKA}

Afridayani. 2016. Faktor Resiko Terjadinya Preklampsia pada Ibu Hamil yang di rujuk ke RSUD dr. Zainoel Abidin', Tesis, Universitas SUmatera Utara, Medan. Diakses dari: http://repository.usu.ac.id/handle/12 $3456789 / 58985$.

Badan Penelitian dan Pengembangan Kesehatan. 2013. Riset Kesehatan Dasar (RISKESDAS) 2013. Laporan Nasional 2013. doi: 1 Desember 2013.

Chen, X. K. et al. 2006. Pregnancy-induced hypertension is associated with lower infant mortality in preterm singletons. BJOG: An International Journal of Obstetrics and Gynaecology, 113(5), pp. 544-51. doi: $\quad 10.1111 / \mathrm{j} .1471$ 0528.2006.00898.x.

Chomaria, N. 2010. Panduan Kehamilan Bagi Muslimah. Surakarta: Cinta Media.

Darusman, D., \& Rafsanjani, T. M. 2018. Pengaruh Pola Konsumsi, Aktivitas Fisik Dan Status Gizi Terhadap Menstruasi Pertama (Studi Kasus Pada Remaja Putri Kelas 1 SMP). Majalah Kesehatan Masyarakat Aceh (MaKMA), 1(1), pp. 20-26.

Dinas Kesehatan Provinsi Aceh. 2014. Profil Kesehatan Provinsi Aceh, Banda Aceh.

Hasan, H. 2007. Hipertensi dalam kehamilan/preeklampsia dan eklampsia (Gestosis). Diakses dari: http://www.universitassumaterautara .com/.

Manuaba. 2010. Ilmu Kebidanan Penyakit Kandungan dan KB. Jakarta: ECG.

Notoatmodjo, S. 2010. Ilmu Perilaku Kesehatan. Cetakan Pertama. Jakarta: Rineka Cipta.

Prawirohardjo, S. 2009. Ilmu Kebidanan. Jakarta: Bina Pustaka.

Pusdatin Kementerian RI. 2014. Infodatin Hipertensi.

Rafsanjani, T. M. 2018. Pengaruh individu, dukungan keluarga dan sosial budaya terhadap konsumsi makanan ibu muda menyusui (Studi kasus di 
Desa Sofyan Kecamatan Simeulue Timur Kabupaten Simeulue). AcTion: Aceh Nutrition Journal, 3(2), pp. 124-131. doi: 10.30867/action.v3i2.112.

Rigina, A. I. 2016. Asuhan Kebidanan Pada Ibu Hamil Dengan Hipertensi Dalam Kehamilan di RSUD Ciamis. KTI; Sekolah Tinggi Ilmu Kesehatan Muhammadiyah Ciamis.

Rohman., D. 2015. Gambaran Sikap Ibu Hamil Dalam Pencegahan Preeklampsia/Eklampsia di Desa Puton Kabupaten Jombang. Jurnal Ilmiah Keperawatan, 1(1). Diakses dari:

https://journal.stikespemkabjombang .ac.id/index.php/jikep/article/view/1 22.

Setyawati., dkk. 2015. Faktor Resiko Hipertensi Pada Wanita Hamil di Indonesia. Jurnal Kesehatan Reproduksi, 6(2), pp. 77-87. doi: 10.22435/kespro.v6i2.4748.77-86.

Sihotang, P. C. et al. 2016. Hubungan Pola Makan Dan Kecukupan Istirahat Tidur Dengan Kejadian Hipertensi Pada Ibu Hamil Di Wilayah Kerja Puskesmas Biromaru. Healthy Tadulako, 2(1), pp. 68-75. doi: ttp://dx.doi.org/10.2030/.v2i1.5747.

Wijaya, F. I. 2014. Hubungan Antara Pengetahuan, Sikap, dan Pola Makan dengan Kejadian Hipertensi Pada Ibu Hamil di Puskesmas Juwana Kabupaten Pati. Skripsi, Universitas Muhammadiyah Surakarta. 